\title{
Polemics on Authority of Wali Nanggroe After Helsinki
}

\author{
T. Irmayani ${ }^{1}$, Haikal \\ Department of Political Science, Faculty of Social and Political Science, \\ University of North Sumatra. \\ tengku.irmayani@gmail.com ${ }^{1}$
}

\begin{abstract}
Constitution Number 11 Year 2006 concerning Aceh Government is the result of the MoU the which includes peace deal between Aceh and the Government of the Republic of Indonesia. The deal was made an Aceh as special regions. Wali Nanggroe Institution led by Malik Mahmud is the result of a privileged Aceh. The position of honor indigenous institutions make-Wali Nanggroe institution has a very strong role in the development process of the political landscape. Although customary function as a formal institution, but from the position of this indigenous Wali Nanggroe institution can play an important role in the development process of the political landscape.

This research Explains how the role of Wali Nanggroe Malik Mahmud in the process of political development in Aceh. Especially in the context of how Democratization and peacebuilding in Aceh post. The theories in this study using role theory, theory and political elites development theory. This study uses qualitative research methodology with descriptive technique based on direct field observations. The presence of Wali Nanggroe Institution has given a new twist in the system of government in Aceh. In this research found there are still many problems related to the presence of Wali Nanggroe but Wali Nanggroe Also have Contributed but not maximum. The collection of data is based on in-depth interviews of secretarial Keurokon Katibul Wali, analysts, researchers, and Activists.
\end{abstract}

Keywords: Role, Political Development, Wali Nanggroe

\section{INTRODUCTION}

In the first clause on the conduct of government in Aceh agreed at point 1.1.7 of the institution of Wali Nanggroe. Wali Nanggroe institution will be established with all its ceremonial attributes and entitlements. Implementation of the MoU gave birth to Act No. 11 of 2006 concerning the Government of Aceh, under the provisions of Article 96 paragraph (4) and Article 97, that further provisions regarding the Wali Nanggroe Aceh Qonun set with number 8 in 2012.

In the structure of the State Cabinet so Aceh, the term is used, namely DR. Tengku Hasan M. di Tiro LLD, as Trustee State which when translated into English Head of State. The term is also contained in the document, when Aceh/Sumatra Nation Liberation Front commemorate the anniversary of independence for 12, 4 December 1976 to 4 December 1988.

In the process of the birth of the institution of Wali Nanggroe begins with the creation of the draft of Qanun (Raqan) about WaliNanggroe in 2010 created by DPRA period 2009-2014 and polemics raises issues related to the authority of the Wali Nanggroe. In Raqan Wali Nanggroe there are a number of points giving prerogatives to the Wali Nanggroe is written in chapter 5 include: running a government authority delegated to the government of Aceh, master asset (wealth) for Aceh within and outside of Aceh, signed a contract of business or employment together with foreign parties, the removal or disabling of Governors (executive), dissolve parliament (legislative), imposed a state of emergency, giving an honorary degree to someone and give legal protection and territorial Aceh.

Post-enactment of Aceh Qanun No. 8 of 2012 on the institution of Wali Nanggroe, Qanun has been revised related on responses of the Ministry of Home Affairs (MOHA) who objected to 21 items 
that was born Qanun No. 9 Year 2013 concerning Aceh Qanun amandement No. 8 of 2012 institution of Wali Nanggroe. Of the Qanun explained that the purpose of establishing the institution of Wali Nanggroe is: unite the people of Aceh, raising DINUL Islam, realizing the people's prosperity, justice, and preserve the peace, maintain the honor (customs, traditions history and civilization Aceh), and make government Acehnese prosperous and dignified.

More controversy is the operational budget of the institution of Wali Nanggroe big enough. And the development of Meuligoe (palace) Wali Nanggroe that has spent 100 billion but still not finished, which is considered a waste of public money. Inversely welfare conditions of the people of Aceh with the poverty rate increased every year. Based on the above background, I was interested in studying the role of Wali Nanggroe in the political development in Aceh. "How Polemic on Authority of Wali Nanggroe After Helsinki".

\section{RESEARCH METHODS}

Research methods used in this research is descriptive research. Descriptive research is the kind of research that aims to explain the beginning of the problem or specific object. Descriptive research conducted to answer a few questions about the state or the object or subject in detail.

Wali Nanggroe Institute is an independent institution. The institute is not a political institution, and beyond as an executive. So Wali Nanggroe Institute is a partner of the Government in rebuilding Aceh. But we are in harmony Khatibul Trustee or Secretariat

It was confirmed by Mr. Fakhrulsyah Mega that: We seek to unify the diverse people of Aceh through the institution of Wali Nanggroe based on customs, culture and history of Aceh. Regarding the geopolitical aspect I think will

But when seen from a government organization working procedures of the

\section{Data Collection Techniques}

In conducting a study, there are several methods used to collect the data include interviews (interview), observation or sighting (observation), and documentation (documentation). To obtain data or information, explanations or facts are needed, the researchers in this study used data collection techniques as follows; primary data and secondary data.

\section{Type Research}

Research type used in this study is a qualitative research method. Researches are methods to explore and understand the meaning by individuals or group of people ascribed social or humanitarian problems. The process of qualitative research involves important efforts, such as asking questions and procedures, collecting specific data from the partisans, analyze the data inductively from the themes specific to the themes are common, and interpret the meaning of data.

\section{RESULTS AND DISCUSSION}

Qonun number 8 of 2012 was revised by the Ministry of Home Affairs in an effort to not exceed the limits of authority granted to the Wali Nanggroe as an institution that was founded as a traditional authorities in the province of Aceh. It is also explained by Mohd. Zaini which is Kassubag Katibul Data Guardian. He explained that:

Institute of Wali Nanggroe is SKPA, administratively we are responsible to the Governor, while our operations are subject to the saint. Almost the same as that existing in the provincial parliament Sekwan

have an effect as well. But the most important is the Wali Nanggroe is actually unifying and leaders of all Acehnese in Aceh civilization, not in terms of politicalpower.

agencies Wali Nanggroe is intended as an traditional institutions.In Government Performance Report (LAKIP) Keurukon 
Katibul Guardian in 2015 that the focus of work Wali Nanggroe institutional issues are customary in Aceh. In work Plan 2015 also working strategy Wali
Nanggroe institution there is a sevenpoint strategy that includes custom development in Aceh.

Table. Indigenous Development Policy Strategies Keurukon Katibul Wali 2015

\begin{tabular}{|l|l|}
\hline No. & \\
\hline 1. & Improvement giving appreciation to deserving advancing civilization Aceh \\
\hline 2. & Increased development of cultural diversity / customs and customs \\
\hline 3. & Improvement of data and information and documentation codex (manuscript) \\
\hline 4. & Improved institutional management and customs regulations Is based on the values of Islam DINUL \\
\hline 5. & the shift function of spectacle culture into demands \\
\hline 6. & Improved support for the provision of data / information in the field of culture and programs \\
\hline 7. & Improved guidance and the preservation and development of the arts, culture, and customs of Islam \\
\hline
\end{tabular}

Source: Work Plan Katibul Wali 2015 (processed Researcher)

Strategies related to this custom shows that the role in promoting the growth of Wali Nanggroe Aceh customary in getting base in the work Plan (working plan) in 2015.Dalam run the working procedures of the organization, institution of Wali Nanggroe also assisted by several assemblies based on a Position Organization Wali Nanggroe with the Aceh Adat Council no problem. In accordance Qanun, the Acehcultur Council function as an institution operating under the Wali Nanggroe. From the legal aspects of personal position rex individual, person Wali, the structure aspect of the state, so the mayor should be assisted by the Ulema Council, Indigenous Assembly, the judges, the Assembly and the Assembly Tuha Mukim Delapan. Majelis-assemblies all support the authority institution of Wali Nanggroe, to support the work the institution of Wali Nanggroe, so that

In Qanun No. 9 of 2013 is explained that there are other assemblies that will help institutional Wali Nanggroe. There Aceh Forestry Council,
particularfield.The position of the current assembly is the assembly of cultur Aceh, and Justice.The presence of this assembly because of the position of trustee as rex individual or positions of authority within the state administration. As explained by the Chairman of MA:

when the guardians run custom tugs all summarized. From side the formal there is a relationship very concrete but could not separated. The function customary guardian Naggroe run, explore, develop, foster and oversee tradition. In qanun existing structure, mentioned of the institution. it as a functional The Aceh Adat Council under the coordination of structural incoming mayor. Wali Nanggroe, large institutions whose bylaws called independent, provide input to the Governor.

the Assembly and the Governor's Khazanah, Aceh Economic Council, Council of Mining and Energy, Council of Social Welfare and Health, and the 
Council of Women. The existence of these assemblies also reinforce the shape that the tendency of Wali Nanggroe institution wants to be the equivalent of an executive agency even exceed exsecutive. As described by the Chairman of the MAA that Wali Nanggroe is a state structure and therefore required the assistance of these assemblies in help job Wali Nanggroe institution.

This is in line with Article 29 that explains explicitly that the Wali Nanggroe can execute control functions of the policies implemented by the provincial parliament and the Governor of Aceh in carrying out this control of policies. The tendency of power and the potential for abuse of power (abuse of of power)the Wali Nanggroe institution is very thick. Unregulated power management that would make the actions of these institutions in the future have to get control of the public good, especially Aceh is still in a state of peace is very important to manage the If we look at the Law Institute of the Government of Wali Nanggroe Aceh say it is tradition. And then his authority leading, fostering institutions determined tradition.

Mawardi Ismail explains the lighting forms of authority inherent in the institution of Wali Nanggroe is setting the governance functions Wali Nanggroe institution's work was sendiri. Any assemblies under actual Wali Nanggroe institution has violated the authority granted by this Nanggroe. It seems like Wali Nanggroe as impressed as Wali president and assemblies as ministers assist in its work of Wali Nanggroe. Impression that there no authority beyond that indeed can be seen over the longer-if it refers to the Qanun No. 9 of 2013 is in the substance of Wali Nanggroe institution is a tradition institution. But if interpreted more far there are chapters that have a tendency Wali Nanggroe institution has a stronger role in government Aceh. One form is transition of power well without any overlapping powers. Judging from the activity and its appearance is the institution of Wali Nanggroe only political game of GAM elite. As seen of function as well, if the institution of Wali Nanggroe deal with customs issues and how the role of the Aceh Adat Council (MAA) which incidentally is also the assembly which is also a traditional institution Aceh. In perception of role theory (role theory) is a thereshadow role inherent in the institution of Wali Nanggroe.

Contributions shadow in question is a pattern tendency seems no interest role in the legitimacy of formal but has a wide range of formal so it is not visible on the surface of the political role of the institution of Wali Nanggroeini. In practice it appears that the role of Wali Nanggroe it outside of indigenous territories. As explained by Mawardi Ismail:

Then again, regulated institutions is not a political institution and not an government institution. well, so this is clearly mentioned in the Law on Governing..Aceh.

less clear division between the assemblies and the institution of Wali Nanggroe maid.

The setting is not clear course will be no end of confusion. Moreover, Wali Nanggroe institution is honored customs agency in charge of indigenous life in Aceh. If there are distortions public authority contrasting it will be argued that the institution of Wali Nanggroe only power pattern wrapped in the customary course. The substance of Qanun No. 9 of 2013 was dominated by an explanation of the customary position of Wali Nanggroe institution-but the emergence of the articles that exceed the authority of this makes also the potential power that exceeds the natural position of mayor institution Nanggroe. Aceh historical which is the customary life 
does deserve preferential treatment in his government. especially run, the current decentralization also entitles regions to manage their own regions. Indeed, on the way from Aceh to make peace with Indonesia are inheritance patterns of violence (violence legacy) and domination (power domination) of the former elite of the Free Aceh Movement in the transition process and the postpeace. Forms of domination that can be done in the form of formal and formal domination informal. The pattern is the actualization of Aceh local political practices embodied in the formation of local political parties.

Aceh Party is the largest local parties in Aceh that many former GAM elite accommodate earlier. begins of governor Joseph, Zaini Abdullah and Muzakir Manaf-even on the way there are potential conflicts of interest in the consolidation of elite GAM in Aceh Party with local parties forming the new outside Aceh Party.

The institution of Wali Nanggroe was originally the highest form of respect to Tiro, a charismatic figure and founder of the Aceh Freedom Movement who build and expand the influence of the separatist movement GAM be reckoned in the world. Sympathy obtained by Hasan Tiro is not only Indonesia, but the world. Proven peace process in Aceh, many involving multiple actors and international institutions to assist the peace process in Aceh. The position of honor inherent in Hasan Tiro when viewed from the role as the founder of GAM cannot be rejected again, in addition to their intellectual abilityHasan Tiro is also an activist organization that is very active in raising

Although unlike in Aceh, Qanun No. 9 of 2013 also have the same legal substance. Despite his political assertion is not clear, but explicitly no meaning more authority than the starting position as an institution costum. as shown in some of the articles that are in the Qanun organization Al-Malik Mahmud GAM. Teuku different Haytar with Hasan Tiro. Teuku Mahmud is a successful businessman who was born in Aceh and to a great career in Singapore and is also involved in the Free Aceh Movement. This condition will automatically process the Acehnese social acceptance by the figure of Wali Nanggroe very difficult. Apart from the issue of the figure of a questionable Teuku Malik Mahmud, also the issue of whether he knows the ins and outs of Aceh together with the ability of Hasan Tiro very well aware about Aceh and contribute substantially to the peace process and the improvement of life in Aceh. A gap between the figure of Hasan Tiro as Wali Nanggroe Aceh community is highly respected by the Wali Nanggroe after Hasan Tiro died, especially those Teuku Mahmud.

Although new in 2012 setting new definitive Wali Nanggroe institution, on the other hand there is a pattern of power consolidation, especially among the elites of former GAM who want to make Aceh within the framework of the imagination of local nationalism that is the legacy of the struggle of the Free Aceh Movement as movements.Some political activities GAM also many who support major changes in Aceh. Moreover, political offices in regencies / cities in Aceh controlled by GAM leaders through the Aceh Party as a local political party that most large and has a network of elite and the mass of the greatest compared to other local parties.

Qanun No. 9 of 2013 is the legal policy and a mandate privilege derived from the MoU and generate Law Number 11 Year 2006 concerning the Government of Aceh.

article 17, article 29 the right of immunity and the right to give direction to the government and the Aceh provincial parliament but if viewed from the Work Plan and Strategic Plan Keurukon Katibul Wali Nanggroe 
institution focus is devoted to the development of indigenous life in Aceh.

Seen in the Draft Qanun previously that the Wali Nanggroe can dismiss the Governor, fire budget. And provincial parliament and control is what makes this Qanun firmly rejected by the central government. In addition to going to promote a system, the role of the elite is also influential in its function as a coercive power (coersive power)coercive power who try to play by the Wali Nanggroe institution if one-a power shift of which has been dominated by the elite GAM. If governance institutions can be referred to as the Wali Nanggroe institution Adhoc role in furthering the political development in the formal framework certainly did not invent ever reached. To achieve the required course work plan Wali Nanggroe. Contributions institutional politics played by Malik Mahmud Wali Nanggroe Teuku more to become a shadow government (shadowstate). The role as a shadow government is more to connectivity among the elite which is currently dominated by the elite of the former GAM.

Teuku Malik Mahmud indeed get the pros and cons of some of the civil society, especially among NGOs that are critical in the process of political development inAceh.The role played by NGOs is very good because it supports the process of political development in Aceh. Evidence complicity of the NGO civil society is community participation in overseeing the Wali Nanggroe institution and also the leadership of Malik Mahmud Teuku as Wali Nanggroe. Because if seen from the presence of the Wali Nanggroe institution even though the mandate of the MoU but the processes occurring in the provincial parliament considerably less than publicparticipation.Public participation is actually very important to play in the process of political development but in practice Qanun discussion about Wali Nanggroe seemed very forced and weak public participation in the drafting process.

Public participation is important for the legitimacy of the institution of Wali Nanggroe public. if customary honor institutions that aims to establish the identity of indigenous life in Aceh certainly Teuku Malik Mahmud role to perform and open space for public participation is important. Critic of YAPPIKA as NGO and watchdog conditions of post-peace civil society see no correlation synergies between the community and the elite-elite Aceh.

Helsinki MoU also contains a
commitment to peace to political
development in Aceh. one of them only
granted privileges Aceh in establishing a
political party this local. This is way the
charges at the time of the conflict can be
achieved through democratic means that
is through political parties and this
election. These considerations seeing
how GAM is the social organization of the
people of Aceh influential-it is necessary
for political development mechanism
that can accommodate political passion
Aceh movement as a political movement.
Overview of Aceh as a federal state with
its privileges, to the process of political
development is also very different from
the political development in other areas.
Factors history of conflict and also to
build the process of political
development in Aceh. Segmentation of
the political elite that contrasts with the
strong local identity also makes an elite
character of the political landscape is
also different from the political elite in
other areas.

Local political elite is very strong at the level of political local focus.Conditions of political development in Aceh are very vulnerable indeed raises the need for the political forces that support the process of political development in Aceh.

Positive role in the sense that this should be run by Wali Nanggroe if it is not the role of the Wali Nanggroe as the 
exalted position would not gain any influence in the process of political development in Aceh. Malik Mahmud Teuku role in the positive sense is not yet fully played by Teuku Malik Mahmud. On the other hand also for the position as Tuah Peut Aceh Party it is also the cause that Teuku Malik Mahmud is a way for GAM to maintain dominance and power in Aceh for years or even forever.

\section{CONCLUSIONS}

Some conclusions of researchers about the role of Wali Nanggroe Teuku Mahmud in political development in Aceh, namely first: lack of regulation Wali Nanggroe role in the political development in the formal legal framework, namely Qonun No. 9 of 2013. In this Qonun explained that the duties and functions of institutions Guardian Nanggroe is customary honorary institution whose task is to develop indigenous life in Aceh. Second: The existence of several articles in the Qonun No. 9 of 2013, which explicitly inclined to add authority Wali Nanggroe role not only as a traditional institution. Third; The institution of Wali Nanggroe is a traditional institution that has an enormous influence in the development process of the political landscape. Although only traditional institutionhistorically this institution has a position of honor in Acehnese society has a practice of indigenous life is very strong.

\section{ADVICE}

Development of indigenous life is very important in the political development in Aceh because of its function as a shaper of ideology leadership in Aceh by custom. Second: The institution of WaliNanggroe Representative must embrace the whole society by holding roadshows and do desimination stricken areas as well as cross-rate discussions. Third: to be able to organize the work of the organization to supervise the Wali Nanggroe institution.

\section{REFERENCES}

Amiruddin, Et.Al. (2007). Aceh Meniti Transisi: Draft Skenario Masa Depan Aceh 2007- 2017. Banda Aceh: YayasanTifa

A. Rani Usman. (2003). Sejarah Peradapan Aceh. Jakarta: Yayasan Obor Indonesia.

Astrid S Susanto. (1983). Pengantar Sosiologi dan Perubahan Sosial, Jakarta: Bina Cipta.

Alfian. (2009). Menjadi PemimpinPolitik. Jakarta: Gramedia.

Bungin, Burhan. (2008). Metode Penelitian Kualitatif. Jakarta: Penerbit Kencana

Blocck, Hubert M. (1987). Pengantar Penelitian Sosial. Terjemahan Yosogama. Jakarta: Rajawali press.

Dodd, CH. (diterjemahkanolehDra. Ratnawati). (1986). Pembangunan Politik. Jakarta: PT Bina Aksara.

Harjanto, NT Budi. (1998). Memajukan demokrasi mencegah disintegrasi: sebuah wacana pembangunan politik. Yogya: Tiara Wacana.

Moleong, Lexsi J. (2001). Metodologi Penelitian Kualitatif, PT. Remaja Rosdakarya.

Natsir, Moh.. (1988). Metode Penelitian. Jakarta: Ghalia Indonesia.

Nurhasim, Moch. Et.Al. (2003) Konflik Aceh: Analisis Atas Sebab-Sebab konflik, Aktor Konflik, Kepentingan dan Upaya Penyelesaian. Jakarta: Proyek Pengembangan Riset Unggulan/Kompetitif LIPI.

Pujiriani. Et.Al. (2010). Panduan Penelitian Lapangan Berperspektif Antar Budaya. Yogyakarta: PSAP UGM Bekerjasama Dengan Found Foundation.

Sulaiman, M. Isa. (2000). Aceh Merdeka: Ideologi, Kepemimpinan dan Gerakan. Jakarta: Pustaka AlKautsar. 
Pusat Pembinaan dan Pengembangan Bahasa. (1988). Kamus Besar
Bahasa Indonesia. Jakarta: PN Balai Pustaka. 